\title{
Economic or Public Health? Southeast Asia's Tackling of COVID-19 a Year Later
}

\author{
Imas Arumsari ${ }^{*}$, Ridhwan Fauzi'2,3, Mohammad Ainul Maruf ${ }^{3,4}$, Mouhamad Bigwanto1
}

\author{
${ }^{1}$ Faculty of Health Sciences, University of Muhammadiyah Prof. Dr. Hamka, South Jakarta, Indonesia \\ ${ }^{2}$ College of Public Health Sciences, Chulalongkorn University, Bangkok, Thailand \\ ${ }^{3}$ Faculty of Public Health, University of Muhammadiyah Jakarta, Indonesia \\ ${ }^{4}$ Global Health and Health Security, College of Public Health, Taipei Medical University, Taiwan
}

\begin{abstract}
The world has been challenged by rapidly spreading COVID-19 outbreaks for a year now. Southeast Asian countries have had different strategies to deal with the pandemic. This review aimed to elaborate on Southeast Asian countries' strategies in managing the trade-off between economic and public health, with further consideration of how such approaches were associated with the dynamics of the number of cases and the speed of economic recovery. This review evaluated the COVID-19 mitigation efforts spanning one year in the Southeast Asian (SEA) countries listed based on the Bloomberg COVID Resilience Ranking. As of May 24, 2021, three SEA countries (Thailand, Malaysia, and Indonesia) were chosen from the better (27th), moderate (35th), and worst (42nd) SEA country rankings. Peer-reviewed articles were obtained from Google Scholar and PubMed databases, and news articles were retrieved from Google News. The data from government websites were also included. Sources were limited to those in the English and Indonesian languages that could be accessed between January 2020 and May 2021. Thailand, Malaysia, and Indonesia were found to have significantly prioritized consideration of the economy in handling the pandemic. Malaysia and Thailand had more stringent policies of imposing national lockdowns, while Indonesia had a partial lockdown. It was found that a weak pandemic response may result in substantial economic loss.
\end{abstract}

Keywords: COVID-19, policy, Southeast Asia

\section{Introduction}

Countries have taken varying approaches to control the coronavirus disease 2019 (COVID-19) pandemic. With these approaches, various indicators can be observed to classify how well a country or government has handled the pandemic. Daily case and death rates have been the most commonly used metrics to determine how each country has addressed the pandemic. ${ }^{1}$ However, it is still difficult to draw any conclusions from the trends of new cases until today. SEA countries showed an increasing pattern in the number of daily cases in the beginning period when the World Health Organization (WHO) first declared COVID-19 as a global pandemic. ${ }^{2}$ Then, the numbers decreased gradually in later periods ${ }^{2}$ as certain countries, with extensive data and experience shared between countries and scientists, which allowed for recognition of the nature of the virus and the formulation of more effective measures. ${ }^{3}$ Following the decrease of new cases, several countries started to loosen restrictions. After the case rate plateaued at the end of 2020 , some countries

Correspondence*: Imas Arumsari, Faculty of Health Sciences, University of Muhammadiyah Prof. Dr. Hamka, South Jakarta, Indonesia, E-mail: imasarumsari@uhamka.ac.id, Phone: +62 8551491965 experienced a second wave of the pandemic. ${ }^{4}$ The dynamics of COVID-19 cases worldwide have prompted the question of what measures governments have taken to consistently control community transmission as the number of daily cases remained low for months but then increased once again.

COVID-19 has challenged government leaders to come up with strategies to control disease transmission at the country level with consideration of the economic impact of such measures. Leadership is an essential aspect of handling a crisis, ${ }^{5}$ and it has been demonstrated to define the course of steps taken during such difficult events. ${ }^{5}$ Accordingly, the actions of leaders concerned about political or business matters have contributed to the fall of their respective nations during times of crisis. ${ }^{6}$ The decision to implement strategies that rely on tradeoffs between the economy and public health might affect the dynamics of the number of cases and the speed of economic recovery. ${ }^{7}$

The Bloomberg COVID Resilience Ranking has tracked 53 countries according to their most negligible

Received : June 8, 2021

Accepted : July 21, 2021

Published: July 31, 2021 
impact on the social, economic, and mortality impact. It was assessed by COVID status (i.e., cases per 100,000 in one month, the one-month fatality rate, total deaths per one million, positive test rate, and percentage of people covered by a vaccine) and quality of life (i.e., lockdown severity, community mobility, 2021 GDP growth forecast, universal health care coverage, and human development index). Southeast Asian (SEA) countries are distributed in the list from the upper to the lower rankings, ${ }^{8}$ which indicates that, aside from their regional and social backgrounds, leadership plays a significant role in controlling the pandemic. Therefore, this review evaluated the progress of one year after the advent of the COVID-19 pandemic by looking at the leaders' decision to enact strategies based on a trade-off between economic interests and public health for COVID-19 mitigation among the SEA countries listed on the Bloomberg COVID Resilience Ranking. Specifically, this paper discussed the efforts of three SEA countries' governments, listed in the ranking as representative of better, moderate, and worse stages during the course of the ongoing pandemic.

\section{Method}

This review included SEA countries on the Bloomberg COVID Resilience Ranking (available online at https://www.bloomberg.com/graphics/COVIDresilience-ranking/). This ranking was chosen because it comprehensively provides an indicator of COVID-19 status and quality of life. The COVID-19 indicators consist of cases per 100,000 in one month, the onemonth fatality rate, total deaths per one million, positive test rate, and the percentage of people covered by the vaccine. The quality of life indicators included lockdown severity, community mobility, 2021 GDP growth forecast, universal health care coverage, and human development index.

The Bloomberg COVID Resilience Ranking tracks 53 countries that are divided into three stages of resiliency: better (rank 1-29), moderate (rank 30-41), and worse (rank 42-53). As of May 24, 2021, three SEA countries were chosen as representatives from each stage. Thailand was selected from the better stage (27), Malaysia from the moderate stage (35), and Indonesia from the worse stage (42).

This review drew upon the information related to the countries' strategies in handling the trade-off between economic interests and public health; it then examined how these approaches affected the dynamics of the number of cases and the speed of economic recovery. An Internet search was conducted in May 2021. Peerreviewed articles were obtained from the Google Scholar and PubMed databases, and news articles were retrieved from Google News. The data from government websites were also included. Sources were limited to those in the English and Indonesian languages that could be accessed between January 2020 and May 2021.

The keywords used in Google Scholar and PubMed were "(Country name)" AND "COVID-19" AND "policy" OR "economy." The search on Google News was performed with the following keywords: "Indonesia," "Malaysia," "Thailand," "COVID-19," "lockdown," "Minister of Health," "policy responses," "law enforcement," and "health-budgeting." The search on government sites was performed to obtain information about policy responses and updates regarding the pandemic's development. A narrative explanation was generated for the discussion. The discussion focused on how three countries managed the trade-off between economic interests and public health from January 2020 to May 2021.

\section{Results}

\section{COVID-19 Situation}

Thailand was the first country outside China to report the novel coronavirus on January $8,2020 .{ }^{9}$ The cases gradually increased in the following weeks of January to February 2020. COVID-19 rapidly spread in the community in March 2020, with hundreds of cases detected daily. ${ }^{9}$ Thailand had successfully contained the first wave of COVID-19 in July 2020, with total cases of about 3,000. However, the total number of cases had skyrocketed to more than 170,000 by June 2021.10

The COVID-19 pandemic started in Malaysia due to imported cases in January 2020.11 This phenomenon resulted in the first wave, with the number of positive cases rising to 22 by February 16, 2020. Since then, the second wave has followed, mainly due to local transmission. The second wave occurred roughly between February and June 2020 and involved a religious gathering at a mosque in Seri Petaling, Kuala Lumpur. ${ }^{12}$ The two waves were handled relatively well, and Malaysian people enjoyed periods of relaxation. Unfortunately, the third wave began in September 2020. With a population of $32,750,801$, Malaysia has so far recorded 616,815 positive cases and 3,378 deaths due to COVID-19 (as of June 8, 2021). ${ }^{13}$

Since its first case in March 2020, the number of cases in Indonesia has been increasing rapidly. While Thailand and Malaysia have faced a second or even third wave, the first wave in Indonesia has yet to cease. As of June 2021, the total number of confirmed cases was $1,831,773$ or 6,697 cases per one million people, with the daily new case rate averaging around 5,000.14 The daily positive rate is the second-highest in Southeast Asia after the Philippines. ${ }^{14}$ This number is considered high in the region, probably due to the lower testing rate. ${ }^{14}$ 


\section{Healthcare Capacity}

The Thai government required that all confirmed cases be admitted to the hospital. ${ }^{9}$ This policy would have backfired without a strong healthcare capacity. Fortunately, Thailand's healthcare system is one of the most robust globally, which is ranked second among 195 countries. ${ }^{9}$ In the last four decades, Thailand has been hugely invested in expanding its health care infrastructure. ${ }^{15}$ In 2019, the total number of hospital beds was about 158,026 from 1,370 hospitals across Thailand, which equals 2.2 beds per 1,000 citizens. ${ }^{15}$ This hospital bed-to-patient ratio may be lower than the average of OECD countries, but it was still sufficient to accommodate all COVID-19 patients during the first wave.9,15 With the demand for care has increased in the recent outbreak; the medical services department set up field hospitals to admit patients with mild or no symptoms. ${ }^{9}$ This strategy successfully reduced the fatality rate to a very low level.

Malaysia has 135 public hospitals, 210 private hospitals, nine special medical institutes, and 61,158 doctors in terms of healthcare capacities. To improve COVID-19 case treatment, the Ministry of Health added 800 new units of medical ventilators to 926 ventilator units already in intensive care unit (ICU) facilities, together with 152 non-invasive ventilators and 142 transport ventilators. ${ }^{16}$ However, the demand may exceed the present resources required to control current and future transmission. ${ }^{17}$

The challenge faced by the Indonesian government in handling COVID-19 has been influenced by health facilities availability in the country. Before the pandemic, Indonesia had one hospital bed per 1,000 people. ${ }^{18}$ Thankfully, the implementation of the large-scale social restrictions (LSSR)/Pembatasan Sosial Berskala Besar $(P S B B)$ has been effective enough to delay hospital admission due to COVID-19 by 20 days. ${ }^{19}$ However, ICUs availability is also needed to handle critical care patients, which is predicted to be $30 \%$ of the total number of hospital admissions due to COVID-19. Meanwhile, Indonesia had 2.7 ICU beds per 100,000 people, which is the fourth-lowest number in Southeast Asia. ${ }^{20}$

\section{Government Response}

The government of Thailand declared a state of emergency on March 26, 2020. The government then implemented strict public health measures, such as promoting personal hygiene, canceling public gatherings, and limiting international and domestic flights. The government also imposed a national lockdown starting on April 3, 2020.9 As of July 2020, the COVID-19 transmission curve was successfully flattened, with around 3,000 cumulative cases being recorded. ${ }^{9}$ The recent surge of COVID-19 can be traced to the nightclub clusters in Bangkok in March 2021. Unlike in the first 92 wave, the Thai government is trying to avoid another national lockdown at all costs to save the economy.

In Malaysia, health examinations at each entry point were among the initial measures enacted to prevent the spread of illness. The next critical steps were to continuously screen and test high-risk individuals and trace and quarantine the contacts. The government also worked hard to increase the number of facilities capable of treating COVID-19 cases. ${ }^{21,22}$ A limited lockdown called a Movement Control Order (MCO) was first announced by Malaysia's Prime Minister on March 18, 2020.23 This order was enacted under the Prevention and Control of Infectious Diseases Act 1988, and the Police Act 1967.22 The education, religious, and secondary sectors were closed, and interstate travel was banned. Only the head of the family could purchase groceries within a 10-kilometer radius. Police and military were deployed to monitor the movements of people. Recently, the government announced a total lockdown amid the COVID-19 surge. ${ }^{24}$ However, it should be noted that many people supported the initial decision to deploy an MCO considering the casualties of the outbreak. ${ }^{25}$

In Indonesia, the national strategy to handle the COVID-19 outbreak has been led by a special committee named Komite Penanganan COVID-19 dan Pemulihan Ekonomi Nasional (Committee for Handling COVID-19 and the National Economic Recovery) ruled by Presidential Regulation No. 82 of 2020. This committee has been led by the Coordinating Minister of the Economy. The Minister of Health serves as the vice head of the committee. During the pandemic, the Minister of Health had been replaced on December 22, 2020. Previously, it has been widely known that the president had been critical of the low COVID-19 actual budget absorption, which was only at $20 \%$, as allocated by the Ministry of Health under the former minister. 26 Indonesia implemented a partial lockdown under the LSSR policy. This consisted of large-scale social regulations, including the closure of public places, schools, restrictions on public transport, and limiting travel. ${ }^{27,28}$ In July 2020, Indonesia entered a new normal period with loosening restrictions in public places. Presidential Instruction No. 26 of 2020, issued on August 4 , encouraged regional leaders to enforce sanctions for not obeying public health protocols. The sanctions included reprimands, social work, administrative fines, or business closures.

\section{Current Economic Situation}

Thailand's economy has been severely impacted by COVID-19, especially since it was in a delicate position even before the global pandemic. ${ }^{29}$ The World Bank estimated that Thailand's economy shrunk by $6.5 \%$ in 2020.29 Thailand's economy heavily relies on international tourism, contributing to approximately 
$12.0 \%$ of the total GDP. ${ }^{29}$ The tourism sector may not be fully recovered in the near future as the pandemic is still far from over. Private consumption also significantly contracted in 2020 despite the government providing 5,000 THB per month in direct cash transfer to individuals affected by the pandemic. ${ }^{29}$ Mobility restriction and physical distancing measures make it increasingly difficult for the private sector to boost the economy. ${ }^{29}$ Therefore, the government could not afford to impose another national lockdown, which would inevitably sink the economy.

Most of Thailand's health budget for the fiscal year 2022 is planned to be allocated to fund universal health coverage and to curb the COVID-19 pandemic. ${ }^{9}$ All COVID-19 medical services are paid by one of three health insurance schemes, including the Civil Servant Medical Benefit Scheme, Social Security Scheme, and Universal Coverage Scheme. ${ }^{9}$ In recent weeks, the Thai parliament agreed to allocate THB 295.7 billion for the health sector in the fiscal year of 2022. Most of this funding would be given to the universal healthcare coverage program, which would account for approximately THB 202 billion. 30

The lockdown has had a significant socio-economic impact on Malaysia's economic performance. In 2020, the GDP was estimated to have contracted 5.6 percent, mainly because of MCO implementation. ${ }^{31}$ To combat the pandemic, the government allocated RM 31.9 billion for the health budget in 2021, which was an increase of $4.3 \%$ from the previous year. The scheme to strengthen the domestic supply chain and boost the production of locally manufactured medical devices will be derived from the new budget, which includes a RM 1.4 billion national development plan. 32

According to the data provided by the Ministry of Finance of the Republic of Indonesia, the country's health budget was planned to be $5 \%$ of the total government budget of 2020.33 Due to COVID-19, the government released Presidential Regulation No. 54 of 2020 as a response to the pandemic to increase the funding in the health sector. It was stated that the change of budget plan should direct the country to focus on controlling the pandemic by sharpening the strategy for health and economic recovery due to the impact of COVID-19.34 The government's consideration to also think about the effects of COVID-19 on the economy has been reasonable. The pandemic has affected broad sectors, including the economy, and the decline of tourism and the high unemployment rate are indications of this effect. ${ }^{35-37}$ In 2020, the GDP contracted by $2.07 \%, 38$ slightly better than the situation in Thailand and Malaysia.

\section{Discussion}

The economy became a significant consideration in formulating COVID-19 response policies in Thailand, Malaysia, and Indonesia. In the short term, there may be a trade-off between economic damage and loss of life. 39 However, the economy may not fully recover without adequately handling the pandemic. In addition, a weak pandemic response has led to substantial economic loss due to premature deaths and "long COVID" related disabilities.

Historically, international tourism has always played a vital role in Thailand's economy. ${ }^{40}$ This sector relies heavily on physical mobility and social interaction. Physical distancing policies enacted during the pandemic have inevitably hurt the tourism industry. Although the tourism sector's contribution has been significant, the Thai government is not in a hurry to fully open the border for international arrivals and loosen physical distancing measures. Public health has remained the top priority in any policymaking during this pandemic. However, a recent Phuket sandbox model proposed by the Tourism Authority of Thailand (TAT) has elicited some critique. This model is the pilot project for re-opening Phuket Island for international vaccinated tourists without mandatory quarantine. ${ }^{41}$ As of June 7, 2021 many issues have not yet been clarified concerning this plan. ${ }^{41}$ Moreover, the Center for COVID-19 Situation Administration (CCSA) has required a minimum of $70 \%$ of Phuket's residents to be vaccinated before tourism can re-open. However, only $60 \%$ of the Island's target vaccination population of 466,587 have received the first shot, and only about 98,795 have been injected with the second shot. 42

To help patients with financial difficulties, Malaysia's Ministry of Health established a special fund known as the COVID-19 Fund. The government and private sectors contributed RM 1 million to this initiative, while NGOs and individuals were also welcome to donate. These funds have also helped those who had no income source during the quarantine and were used to support medical expenses and treatment processes. ${ }^{43}$ Malaysia has viewed this COVID-19 crisis as a public health crisis first and an economic crisis second. Thus, the economic policy was mainly focused on supporting public health measures to combat the pandemic while also protecting people's and businesses' wellbeing. ${ }^{4}$

Strategies designed to boost the tourism sector also received the Indonesian government's attention at the beginning of the pandemic. In February 2020, when other countries decided to close the border because of the outbreak, the Indonesian government decided to provide a $30 \%$ discount for domestic and overseas tourists to boost the weakened tourism sectors due to the economic impact of COVID-19 worldwide. ${ }^{45}$ Similar 
tourism policies have gained criticism from the public. Currently, the Indonesian government is focusing on economic recovery, including the provision of stimulus payments for the tourism sector. These stimuli include IDR 3.3 trillion in grants for hotels and restaurants. ${ }^{46}$

Speeding up vaccination rollouts is a win-win solution for public health and economic recovery. Nevertheless, vaccination rollouts have been relatively slow in Thailand. The Bloomberg Resilience Ranking recorded only $2.1 \%$ of the Thai population as being vaccinated as of June $7,2021.8$ The low vaccination rate may hinder the control of COVID-19 transmission in Thailand, which has been stagnant. COVID-19 cases have been reported at around 2,000 per day in the past month. ${ }^{10}$ The government currently relies on the Sinovac and Oxford-AstraZeneca vaccines. Therefore, the government plans to speed up mass vaccination by injecting THB 3.59 billion into vaccination procurement and management. ${ }^{47}$ In addition, a total of THB 2.379 billion would be allocated to the National Vaccine Institute for the development and manufacturing of locally made COVID-19 vaccines. ${ }^{47}$

Only $7.3 \%$ of the Malaysian population have received at least one dose of the COVID vaccine. ${ }^{48}$ Accordingly, the government plans to accelerate its national vaccination program. It is expected to reach the $80 \%$ vaccination target by August 2021.49 The total RM 5 billion federal COVID-19 vaccine program allocation has not been taken out from the country's budget. Yet, it was taken from the Pemerkasa economic stimulus package and the National Trust Fund (KWAN) - a savings fund built from Malaysia's natural resources, primarily through a donation from the oil and gas company, Petronas. This policy has been implemented to avoid a GDP deficit. 50

In Indonesia, the total health budget in 2021 has been focused on the vaccination program. As the vaccination program became a priority, by June $2,2021,6 \%$ of the total population had received at least one dose of a vaccine. ${ }^{14}$ This is a notable effort for a country with a large population. However, the education of the community regarding the concept of herd immunity needs to be improved. People need to be educated that wearing masks, washing hands, and avoiding crowds are still required even after completing two vaccination shots. Education with effective communication strategies is essential during outbreaks since well-educated citizens contribute to the collective approach of optimizing government regulations. ${ }^{51}$ Moreover, the target vaccination rate in Indonesia has been set at $70 \%$ of the total population. Looking at the current achievement, the number of people vaccinated is still far from this goal.

Thailand was recognized as one of the best countries in curbing the COVID-19 spread in $2020 .{ }^{9}$ However, the situation may differ in 2021. A recent surge of COVID19 cases began in the Greater Bangkok Area, ${ }^{10}$ as the virus was transmitted rapidly to all provinces after the Songkran holiday. ${ }^{10}$ Although the street water fight was banned this year, many Thais still took a trip to their hometowns. ${ }^{52}$ Policy responses have included issuing a nationwide mask mandate, closures of entertainment venues and businesses, and limits on restaurant and store operations. ${ }^{52}$ Despite the daily confirmed case number being equal to all cases during the entire first wave period (January-July 2020), the Thai government is hesitant to impose a strict national lockdown to avoid more profound economic damage.

At the beginning of the pandemic, Malaysians were unaware of the virus's lethality and unprepared to deal with the pandemic, mainly because of the simultaneous political crisis and the conviction that the virus would not spread quickly in Malaysia. ${ }^{21}$ However, Malaysian people began to panic when the first two deaths were reported in mid-March, less than a week after Malaysia's positive COVID-19 cases jumped from 99 to 200 at the start of the second wave. ${ }^{53}$ As a result, the government has taken numerous actions to assuage public concern and safeguard Malaysian citizens' health.

The dilemma regarding the prioritization of the economy or health in Indonesia has led the nation to be ill-prepared in taking all the necessary measures to strictly limit public mobilization, even though the number of daily cases has increased steadily compared to neighboring countries. ${ }^{54}$ Instead of a total lockdown, Indonesia implemented a partial lockdown under the LSRR policy; a large-scale social restriction including the closure of public places and schools and limitations on public transport and other travel. ${ }^{27,28}$ In July 2020, Indonesia entered a new normal period with loosening restrictions on public places. This has encouraged the mindset in the public that COVID has ended. Moreover, there is a lack of positive laws regulating fines for not wearing masks, washing hands, or keeping distance. The decline of $P S B B$ restrictions came in line with the occurrence of long holidays. From October to November 2020, there were several public holidays, and the daily number of new cases increased after these days. For instance, it can be seen from the data that the number of confirmed cases increased steadily after the public holiday on November 5, 2020.14

\section{Conclusion}

At the beginning of the pandemic, Malaysia and Thailand implemented strict national lockdowns. These policies had successfully contained the spread of COVID19 in 2020, but Indonesia's health system was on the brink of collapse at the same time. However, the performance of the economic indicator was slightly 
better in Indonesia, while Malaysia and Thailand's economies hit rock bottom.

No country could afford a strict lockdown forever because the pandemic may not disappear soon. Therefore, the authors recommend a combination of moderate control with solid law enforcement and the provision of cash transfers and other social assistance programs as a strategy to save lives and livelihoods. Second, complacency, the loosening of public health restrictions, and slow vaccination rollouts may have contributed to the recent surge of COVID-19 in the region. All Southeast Asian countries have been relatively slow to provide COVID-19 vaccinations. Therefore, speeding up vaccination rollouts is the crucial solution to flatten the COVID-19 infection curve in Thailand, Malaysia, and Indonesia.

\begin{abstract}
Abbreviations
COVID-19: coronavirus disease 2019; SEA: Southeast Asia; WHO: World Health Organization; GDP: Gross Domestic Product; ICU: intensive care unit; LSSR: large-scale social restrictions/Pembatasan Sosial Berskala Besar; MCO: Movement Control Order; OECD: Organization for Economic Co-operation and Development.
\end{abstract}

\section{Ethics Approval and Consent to Participate}

This research does not involve humans or other living creatures as samples. No formal ethical scrutiny was required or undertaken.

\section{Competing Interest}

The authors declare there is no conflict of interest.

\section{Availability of Data and Materials \\ Not applicable.}

\section{Authors' Contribution}

IA conceptualized the review objective and framework. RF, MA, and $\mathrm{MB}$ conducted a literature search. All authors work together on synthesizing information.

\section{Acknowledgment \\ Not applicable.}

\section{References}

1. Fan G, Yang Z, Lin Q, Zhao S, Yang L, He D. Decreased case fatality rate of COVID-19 in the second wave: a study in 53 countries or regions. Transboundary and Emerging Diseases. 2021;68(2):213-5.

2. World Health Organization. Confirmed and probable COVID-19 cases and deaths by age from WHO COVID-19 surveillance data dashboard; 2021.

3. de Bruin YB, Lequarre A-S, McCourt J, Clevestig P, Pigazzani F, Jeddi $\mathrm{MZ}$, et al. Initial impacts of global risk mitigation measures taken during the combatting of the COVID-19 pandemic. Safety Science. 2020;128:104773.

4. World Health Organization. WHO COVID-19 dashboard Geneva;
2020.

5. Kerrissey MJ, Edmondson AC. What good leadership looks like during this pandemic. Harvard Business Review. 2020; 13(1).

6. Wilson S. Pandemic leadership: lessons from New Zealand's approach to COVID-19. Leadership. 2020;16(3):279-93.

7. Lin Z, Meissner CM. Health vs. wealth? Public health policies and the economy during COVID-19. National Bureau of Economic Research; 2020.

8. Bloomberg. The COVID resilience ranking; 2021 [cited June 7, 2021].

9. Sirilak S, Iamsirithaworn S, Hinjoy S, Janejai N, Thaiprayoon S, Keawpramkusol R, et al. Thailand's experience in the COVID-19 response. Bangkok: Ministry of Public Health of Thailand; 2020 [cited 20211 May].

10. Department of Diseases Control. The coronavirus disease 2019 situation Bangkok. Ministry of Public Health of Thailand; 2020.

11. New Straits Times. 3 Coronavirus cases confirmed in Johor Baru. New Straits Times; 2020.

12. Edinur HA, Safuan S. Sri Petaling COVID-19 cluster in Malaysia: challenges and the mitigation strategies. Acta Biomedica. 2020; 91(4).

13. Worldometer. COVID-19 coronavirus pandemic; 2021 [cited June 7 2021].

14. Our World in Data. Coronavirus pandemic (COVID-19); 2020.

15. Marome W, Shaw R. COVID-19 response in Thailand and its implications on future preparedness. 2021 [cited 20211 May]; 18(3).

16. Zainul E. Health Ministry places order for 800 new ventilators for COVID-19 treatment. The Edge Markets; 2020 [cited 2021 June 7].

17. Hamzah NM, Yu MM, See KF. Assessing the efficiency of Malaysia health system in COVID-19 prevention and treatment response. Health Care Management Science. 2021:1-13.

18. Data World Bank. Hospital beds (per 1,000 people) - Indonesia; 2021.

19. Shidiq AR. Our health system's capacity vs demand from large-scale social distancing. The Jakarta Post; 2020.

20. Phua J, Faruq MO, Kulkarni AP, Redjeki IS, Detleuxay K, Mendsaikhan N, et al. Critical care bed capacity in Asian countries and regions. Critical Care Medicine. 2020; 48(5):654-62.

21. Shah AUM, Safri SNA, Thevadas R, Noordin NK, Abd Rahman A, Sekawi Z, et al. COVID-19 outbreak in Malaysia: actions taken by the Malaysian government. International Journal of Infectious Diseases. 2020;97:108-16.

22. Salim N, Chan WH, Mansor S, Bazin NEN, Amaran S, Faudzi AAM, et al. COVID-19 epidemic in Malaysia: impact of lockdown on infection dynamics. medRxiv; 2020.

23. Bunyan J. PM: Malaysia under movement control order from Wed until March 31, all shops closed except for essential services Malaysia. Malaymail; 2020.

24. Teoh S. Malaysia to impose total nationwide lockdown from June 1-14 as COVID-19 cases hit new record. The Straits Times; 2021 [cited 2021 June 7].

25. Yu Z, Razzaq A, Rehman A, Shah A, Jameel K, Mor RS. Disruption in global supply chain and socio-economic shocks: a lesson from COVID-19 for sustainable production and consumption. Operations Management Research. 2021:1-16.

26. Hakim RN. Lagi, Jokowi sentil para menteri soal rendahnya realisasi anggaran COVID-19. Kompas.com; 2020. 
Kesmas: Jurnal Kesehatan Masyarakat Nasional (National Public Health Journal). 2021; 16 (Special Issue 1): 90-96.

27. Nugraheny DE. Ketua Dewan Guru Besar FKUI sarankan pemerintah lockdown daerah terjangkit COVID-19. Kompas.com; 2020.

28. The Jakarta Post. COVID-19: Ombudsman slams govt for 'focusing too much on economic recovery; 2020.

29. The World Bank. Thailand economic monitor January 2021: restoring incomes; recovering jobs. Wahsington, DC: The World Bank; 2021.

30. Theparat C. B205bn health budget agreed. Bangkok Post; 2021.

31. Department of Statistics Malaysia. Malaysia economic performance fourth quarter 2020. Department of Statistics Malaysia; 2021 [cited 2021 June 7].

32. Administration IT. Malaysia healthcare. International Trade Administration; 2020 [cited 2021 June 7].

33. Kementerian Keuangan Republik Indonesia. Anggaran pendapatan dan belanja negara 2020. In: Ministry of Finance, editor; 2020.

34. Kementerian Keuangan Republik Indonesia. Perubahan postur dan rincian APBN 2020 di masa pandemi COVID-19 [press release]; 2020.

35. Rizal JG. Pandemi COVID-19, apa saja dampak pada sektor ketenagakerjaan Indonesia? Kompas.com; 2020.

36. Guridno E, Guridno A. COVID-19 impact: Indonesia tourism in new normal era. Int J Manag Humanit. 2020; 4(11):31-4.

37. Susilawati S, Falefi R, Purwoko A. Impact of COVID-19's pandemic on the economy of Indonesia. Budapest International Research and Critics Institute (BIRCI-Journal): Humanities and Social Sciences. 2020; 3(2):1147-56.

38. Badan Pusat Statistik. Ekonomi Indonesia 2020 turun sebesar 2,07 persen (c-to-c) [press release]; 2021.

39. Casey BH. COVID-19: is there a trade-off between economic damage and loss of life? London: The London Scholl of Economics and Political Science; 2020.

40. Janjua LR, Muhammad F, Sukjai P, Rehman A, Yu Z. Impact of COVID-19 pandemic on logistics performance, economic growth and tourism industry of Thailand: an empirical forecasting using ARIMA. 2021 [cited 20211 May]; 18(2):1-15.

41. Taylor M. PM to chair meeting on Thailand's re-opening as Phuket officials demand clarity. The Thaiger; 2021 [cited 2021 June 7].

42. Theparat C. Phuket set for July re-opening Bangkok. Bangkok Post; 2021 [cited 20217 June].

43. The Star. COVID-19: public can now contribute to Health Ministry. The Star; 2020 [cited 2021 June 7].

44. Cheng C. COVID-19 in Malaysia: economic impacts \& fiscal responses. Institute of Strategic and International Studies Malaysia; 2020.

45. Prasetia A. Genjot pariwisata di tengah corona, Jokowi beri turis diskon. Detik News; 2020.

46. Kementerian Koordinator Bidang Perekonomian Republik Indonesia. Pemerintah gelontorkan berbagai stimulus dorong pemulihan sektor pariwisata [press release]; 2021.

47. Wipatayotin A, Theparat C. B6bn COVID vaccine budget Bangkok. Bangkok Post; 2020 [cited 20217 June].

48. Ritchie H, Ortiz-Ospina E, Beltekian D, Mathieu E, Hasell J, Macdonald B, et al. Coronavirus (COVID-19) vaccinations. Our World in Data; 2021 [cited 2021 June 7].

49. Lee YN. Malaysia's COVID lockdown puts 'a lot of pressure' on government finances, says minister. CNBC; 2021 [cited 2021 June 7].

50. CodeBlue. Minister: RM3 bil COVID-19 vaccine allocation not in budget 2021. CodeBlue; 2021 [cited 2021 June 7].

51. Ayuningtyas D, Haq HU, Utami RRM. Initiating global civil society as a strategy for handling the COVID-19 public health threat: a policy review. Kesmas: Jurnal Kesehatan Masyarakat Nasional (National Public Health Journal); 2020.

52. Gunia A. Southeast Asia kept COVID-19 under control for most of the pandemic. Now it's battling worrying new surges Hong Kong. Time; 2021.

53. Majid TSM. COVID-19: panic and the Malaysian economy. New Straits Times; 2020 [cited 2021 June 7].

54. Sparrow R, Dartanto T, Hartwig R. Indonesia under the new normal: challenges and the way ahead. Bulletin of Indonesian Economic Studies. 2020;56(3):269-99. 